\title{
LEVEL OF KNOWLEDGE IN PREGNANT WOMEN ABOUT ANEMIA IN SUKAMULYA AND TAROGONG PUBLIC HEALTH CENTER
}

\author{
Annisa Apriliani ${ }^{1}$, Tetti Solehati $^{2)}$, Sukmawati $^{3}$ ) \\ Email : tetti.solehati@unpad.ac.id \\ ${ }^{123}$ Fakultas Keperawatan Universitas Padjajaran \\ Jl. Raya Bandung Sumedang KM.21, Hegarmanah, Kecamatan Jatinangor, \\ Kabupaten Sumedang, Provinsi Jawa Barat 45363
}

Article Information

Received:

September 27, 2019

Revised:

December 15, 2019

Accepted:

January 19, 2020

Available online:

January 23, 2020

\begin{abstract}
Anemia among pregnant mothers in Garut Regency in 2018 still appears to be high beyond the national target. The highest rate happened in Sukamulya Public Health Center, and the lowest rate was at Tarogong Public Health Center. One of the factors influencing anemia is the level of knowledge among pregnant mothers. This study aimed to determine the level of knowledge among pregnant mothers on anemia in Sukamulya and Tarogong Public Health Center. The design used in this study was descriptive quantitative. The population in this research was pregnant mothers with anemia in Sukamulya and Tarogong Public Health Center. The sample taken in this study was 69 participants in Sukamulya Public Health Center, and 95 participants in Tarogong Public Health Center gained by accidental sampling technique. The data collection conducted from May to June 2019 and analyzed using univariate. The result showed that there was a difference in the level of knowledge of pregnant mothers on anemia. In Sukamulya Public Health Center, almost $46.44 \%$ of participants had a lack of knowledge of the causes of anemia in pregnant mothers, meanwhile, in Tarogong Public Health Center, almost $49.5 \%$ had sufficient knowledge of anemia. It concluded that there was a different level of knowledge among pregnant mothers on anemia. Pregnant mothers in Sukamulya categorized had inadequate knowledge and for pregnant mothers in Tarogong categorized had sufficient knowledge about anemia. There is an intended value that the authors suggest, the public health centre must improve the knowledge among pregnant mothers on anemia through health counselling and seminar, especially regarding the knowledge on the cause of anemia among pregnant mothers in Sukamulya Public Health Center.
\end{abstract}

Keywords: Anemia, Pregnant Mothers, Knowledge

\section{Introduction}

According to the World Health Organization (WHO) in the world in 2015, there was a Maternal Mortality Rate (MMR) of 303,000 deaths ${ }^{[1]}$.Maternal mortality is one indicator of the success of health services in a country to determine the level of awareness of healthy living behaviours, nutritional status, maternal health, environmental health conditions, and the level of health services for pregnant women, mothers giving birth and childbirth. Maternal mortality in Indonesia is still quite high compared to other countries in ASEAN ${ }^{[2]}$.According 
to the results of the Indonesian Demographic and Health Survey (SDKI) in 2015, maternal mortality was around 305 per 100,000 births. It was still higher than and the Sustainable Development Goals (SDGs) target by 2030, which maternal mortality expected to be below 70 per 100,000 live births. The number of maternal mortality in West Java in 2016 was 797 and Garut regency ranked first with 74 cases $^{[3]}$.According to the World Health Organization (WHO) in 2018, the prevalence of anemia in pregnant women was $51 \%$, while the anemia that occurs in non-pregnant women was $35 \%$. Based on the results of the Basic Health Research in 2013, it showed that the anemia rate in pregnant women was $37.1 \%$ and increasing to $48.9 \%$ in $2018^{[4]}$. West Java in 2016 showed a prevalence of anemia in pregnant women was $37.1 \% .^{[5]}$

Anemia in pregnancy is a significant public health problem, especially in developing countries. Pregnant women with anemia will affect physical activity, increased morbidity and mortality, especially in pregnant women with severe anemia ${ }^{[6]}$. The most common causes of anemia in pregnancy are iron deficiency, folic acid and acute bleeding ${ }^{[7]}$. According to Lawrence Green (1993) in Notoatmodjo (2014), a person's health behaviour is influenced by knowledge. Good knowledge can support the behaviour of pregnant women to prevent anemia. ${ }^{[8]}$

Based on the results of a study conducted by Maulida and Darmawati (2018) in Darussalam Public Health Center, showed that the level of knowledge was higher, namely 41 respondents $(64.1 \%)$ and 23 respondents $(35.9 \%)$ had low levels of knowledge. It concluded that there was a relationship between knowledge factors and the incidence of anemia in pregnant women. To prevent anemia in pregnant women must be addressed immediately. If the mother was already anemic, efforts must be made by the pregnant woman herself or her family. Therefore, it is necessary to have good knowledge of anemia.
Pregnant women who have less knowledge about anemia will behave disobediently to make efforts to prevent and overcome them, and pregnant women who have good knowledge will be obedient in making prevention of anemia in pregnant women. ${ }^{[9]}$

In Garut regency, the number of anemia in pregnant women in 2017 reached $24.52 \%$. These results illustrate that the incidence of anemia in pregnant women was higher than the national target of $20 \%{ }^{[10]}$. In 2018 the incidence of anemia in pregnant women increased by $4.01 \%$ to $28.53 \%$. Of 67 Puskesmas in Garut regency, Sukamulya Public Health Center ranks first among pregnant women with the highest anemia, which was $137(30.44 \%)$ people out of 450 pregnant women while the Tarogong Public Health Center ranks lowest at 38 $(10.67 \%)$ of 356 pregnant women. ${ }^{[11]}$

From a preliminary study conducted on March 14, 2019, through interviews with seven pregnant women, only two people had attended health education. According to the health officer in charge of Maternal and Child Health, the incidence of anemia in pregnant women at the Sukamulya Public Health Center due to noncompliance with consuming iron tablets. The majority of pregnant women complain the iron tablets were smelly, so they did not want to take them and sometimes pregnant women forget to take iron tablets at night. Also, many mothers were found to be close to pregnancy and childbirth. Efforts that have been made by the Sukamulya Public Health Center to reduce the number of anemia in pregnant women were by giving iron tablets and supplementary feeding for pregnant women and health education every month to each village regarding prevention of anemia during pregnancy signs and danger of pregnancy. However, no evaluation has been carried out from the results of the counselling.

The results of a preliminary study in Tarogong Public Health Center on March 15, 2019, through interviews with 
five pregnant women, showed that mothers had attended health education, but sometimes mothers forgot about the material that had been delivered. According to the health officer in charge of maternal and child health, the Public Health Center has formed a class for pregnant women and provides health education every time they came to get an exam. In Tarogong Public Health Center also has health facilities that care for pregnant women, namely the availability of Communication, Information and Education (KIE). The counselling conducted by midwives and nurses in every four villages, including about anemia. If anemia was detected, pregnant women were given additional food and iron tablets.

This study conducted at two different Public Health Center to see differences in the level of knowledge of pregnant women about anemia, because seen from the highest incidence of anemia in pregnant women were at Sukamulya Public Health Center, because it is far from the population, and the lowest was at Tarogong Public Health Center because it is close to residential areas. Also, the extension program to each village was always routine every month. However, the differences in the Tarogong Public Health Center were accompanied by forming classes for pregnant women routinely every week, that was the reason why the study should be conducted to see the knowledge of pregnant women about anemia in the Sukamulya and Tarogong Health Center.

\section{Method}

This study was quantitative using a descriptive design. Data collection was carried out in May-June 2019 at the Sukamulya and Tarogong Public Health Center. The population in this study were 69 pregnant women at Sukamulya Public Health Center and 95 pregnant women in Tarogong Public Health Center (average monthly visit in January-May 2019) by taking samples using accidental sampling.

The instrument was questionnaire sheet which consisted of: (a) data on name, age, occupation, education, source of information, the distance of pregnancy, gestational age and (B) knowledge about anemia. Authors made this questionnaire with references from Ani (2013), Ministry of Health (2009), Fatmah (2010), Mochtar (2012), Manuaba (2010), Prahesti (2017), Proverawati (2017), and Soebroto (2010) consisting of 27 questions. The questionnaire filled by circling one of the answers.

Data collected using a questionnaire to respondents who came for a pregnancy check. Then, the authors explained the purpose and objectives of the study and asked the respondents' willingness to fill out the questionnaire. Respondents fill out questionnaires by filling in demographic sheets and knowledge sheets, during the questionnaire filling, respondents accompanied by authors. The collected data then analyzed univariately.

\section{Results and Discussion}

a. Demographic Characteristics of Respondents

Table 1 Frequency Distribution of Respondents Characteristics in Sukamulya $(n=69)$ and Tarogong ( $\mathrm{n}=95)$ Public Health Center

\begin{tabular}{lcccc}
\hline \multirow{2}{*}{ Characteristic } & \multicolumn{2}{c}{ Sukamulya } & \multicolumn{2}{c}{ Tarogong } \\
\cline { 2 - 5 } & f & \% & f & \% \\
\hline Age & & & & \\
$<$ 20 years old & 7 & 10.2 & 13 & 13.7 \\
20-35 years old & 53 & 76.8 & 70 & 73.7 \\
$>$ 35 years old & 9 & 13.0 & 12 & 12.6
\end{tabular}




\section{Occupation}

Working

Not Working

\section{Education Hystory}

No Education

Elementary School

Junior High School

Senior High School

\section{Information Exposure}

Exposed

Unexposed

Information Sources

Cadre

Public Health Center

Internet

Others

Parity

0-3

\section{Gestational Age}

First Trimester (0-12 weeks) 17

Knowledge is one of the factors that influence health behaviour. If pregnant women know and understand the effects of anemia and how to prevent it, they will have good health behaviours so that they can avoid the various risks or consequences of anemia in pregnancy. The health behaviour can also affect the reduction in the incidence of anemia in pregnancy. Anemia can be influenced by several aspects including age, socioeconomic status, education, experience and other aspects. ${ }^{[12]}$

Based on the results of the study showed that most pregnant women in Sukamulya and Tarogong Public Health Center were correctly understood about anemia, especially regarding the question that stated anemia is most vulnerable to pregnant women. At Sukamulya Public Health Center, the majority of respondents understood blood deficiency as anemia. The knowledge of pregnant women about the definition of anemia at the Tarogong was higher than at Sukamulya. Factors that might affect knowledge about anemia can be influenced by age. According to Notoatmodjo ${ }^{[12]}$,age influences knowledge related to one's comprehension and one's mindset. The older a person is, the higher their level of knowledge and mindset because they had more time interacting in the community to find information. Other research stated that age is a factor that influences pregnancy both in the readiness of the reproductive organs, experience or knowledge of pregnant women. ${ }^{[14]}$

Martini stated that (15) in the 20-35 years age group, it was easier to understand the explanations and information conveyed by various media or medical personnel. Based 
on the respondents' characteristics, it was found that the majority of respondents aged 20-35 years were $76.8 \%$ in the Sukamulya and Tarogong Public Health Center was $73.7 \%$. It concluded that there was no relationship between knowledge level and age of respondents.

Based on the results of the study showed that most of the respondents in Sukamulya and Tarogong Public Health Center answered correctly about signs of anemia such as easily weak, tired, lethargic, hard to concentrate. Mother's knowledge was mostly in the poor category; this could be influenced by maternal education factors which constitute the majority of junior high schools (44.9\%) in the Sukamulya Public Health Center. According to Wulandini ${ }^{[16]}$, lack of knowledge can be caused by education. The low education would also affect the absorption or reception of incoming information. Mother's education affects the degree of health because knowledge and understanding of something could lead to positive health behaviours. So it can be said that the higher the education, the better the level of knowledge. Conversely, the lower the level of education, the mindset becomes low so that the absorption of information is also reduced..$^{[17]}$

Most mothers had never received information about anemia at Sukamulya $(50.7 \%)$ which was higher than mothers who had received information at Tarogong $(75.8 \%)$ and information that mothers got mostly from cadres at Sukamulya $(20,3 \%)$. Cadre is an extension of health workers who have a role in health services such as at the posyandu; besides, mothers met more frequently than with other health workers ${ }^{[18]}$. The knowledge of health cadres about anemia in pregnancy could cause positive changes for mothers because the knowledge of health cadres will be transformed to the pregnant women in the vicinity. ${ }^{[19]}$

Whereas in Tarogong

Puskesmas, the knowledge of pregnant women was in a sufficient category. This result can be influenced by educational factors where the majority of respondents were high school graduates $(56.8 \%)$. According to Cahyonoputra in Wulandini ${ }^{[16]}$, information obtained from both formal and non-formal education could have an immediate impact so that it could produce changes or increase knowledge. Apart from Tarogong Puskesmas, respondents received information from the internet $(25.3 \%)$ or mass media such as print media (magazines, newspapers) and electronics (television, radio) which by using the internet made it easier to get the required knowledge and information.

Based on the results of the study, it showed that most of the respondent in Sukamulya answers questions about the causes of chronic anemia due to intestinal worms. While in Tarogong, most respondents answered the cause of anemia due to lack of iron in the diet. Knowledge of pregnant women about the causes of anemia in pregnant women was lower at the Sukamulya Public Health Center compared to Tarogong Public Health Center, possibly influenced by the mother's experience during her pregnancy. Multigravida will have more experience than primigravida, whereas most mothers in the Sukamulya Public Health Center (84.1\%) and Tarogong Public Health Center (77.9\%) were primigravidas.

Based on the results of the study showed that most of the respondents in Sukamulya Public Health Center answered correctly to the question of anemia can give a bad influence on the fetus, namely 
the low birth weight of the baby. While in Tarogong Public Health Center, answering the question of the impact of anemia on pregnancy is bleeding can occur during childbirth. Respondent knowledge in the Tarogong was higher than in the Sukamulya. Age when the women pregnant could influence the incidence of anemia, where at a young age requires more nutritional intake because young people are prone to suffer from anemia in pregnancy and will be very vulnerable to bleeding and infection $^{[12]}$. Lack of knowledge about the benefits of nutrition during pregnancy can cause pregnant women to lack nutrition and result in anemia. ${ }^{[20]}$

The results of the study showed that most of the respondents in Sukamulya Public Health Center correctly answered the question of the type of food that can prevent anemia, namely by giving iron tablets and vitamin C. While in the Tarogong Health Center answering correctly for questions about food sources that contain lots of iron, namely spinach. Occupational factors could influence this result. Pregnant women who did not work to be less sociable, so they got less information. Handayani. ${ }^{[21]}$ stated that one of the indirect causes occurs in pregnant women with anemia was the occupational status of the mother. Occupational status was closely related to education as well as one's income or family income. $82.6 \%$ of pregnant women were housewife in the working area of Sukamulya Puskesmas, and Tarogong Health Center was 69.5\%, they were more prone to anemia than working mothers. Anemia can occur in mothers who did not work because usually, they had lower incomes, so they lack access to buy foods that contain enough iron. b. Comparison of Pregnant Women's Knowledge about Anemia in Sukamulya and Tarogong Public Health Center

Table 2 Comparison of Pregnant Women's Knowledge about Anemia in Sukamulya and Tarogong Public Health Center

\begin{tabular}{lcccccc}
\hline \multirow{2}{*}{ PHC } & \multicolumn{2}{c}{ Excellent } & \multicolumn{2}{c}{ Sufficient } & \multicolumn{2}{c}{ Poor } \\
\cline { 2 - 7 } & f & \% & f & \% & f & \% \\
\hline Sukamulya & 11 & 15.9 & 26 & 37.7 & 32 & 46.4 \\
Tarogong & 21 & 22.1 & 47 & 49.5 & 27 & 28.4 \\
\hline
\end{tabular}

The majority of pregnant women in Sukamulya Public Health Center had lacked knowledge about anemia which was $46.4 \%$ and $49.5 \%$ respondents in Tarogong Public Health Center had sufficient knowledge. It showed that there were differences in the level of knowledge of pregnant women about anemia. Different from the research of Kusumawati ${ }^{(22)}$ showed that entirely (90.9\%) had excellent knowledge, sufficient knowledge $(9.1 \%)$, and there were no respondents with less knowledge.

Respondents' knowledge was obtained by providing health education interventions from health workers. Health education about anemia aims to provide information to respondents about anemia so that respondents' knowledge is excellent and can avoid anemia - health education as a form of training or education held to increase supporting knowledge. ${ }^{[13]}$ The increasing knowledge of pregnant women shown from the change of pregnant women attitude in maintaining a better pregnancy, especially regarding anemia in pregnancy. According to Wijayanti ${ }^{[14]}$, three factors can influence the success of health education, namely counselling factors, goals and the counselling process. 
Table 3 Frequency Distribution Based on Indicators of Knowledge Levels of Pregnant Women at Sukamulya and Tarogong Public Health Center

\begin{tabular}{|c|c|c|c|c|c|c|c|c|}
\hline \multirow{3}{*}{$\begin{array}{c}\text { Indicator } \\
\mathbf{s}\end{array}$} & \multicolumn{4}{|c|}{ Sukamulya } & \multicolumn{4}{|c|}{ Tarogong } \\
\hline & \multicolumn{2}{|c|}{ Know } & \multicolumn{2}{|c|}{$\begin{array}{c}\text { Did not } \\
\text { know }\end{array}$} & \multicolumn{2}{|c|}{ Know } & \multicolumn{2}{|c|}{$\begin{array}{c}\text { Did not } \\
\text { know }\end{array}$} \\
\hline & $\mathbf{f}$ & $\%$ & f & $\%$ & $\mathbf{f}$ & & $\mathbf{f}$ & $\%$ \\
\hline \multirow[t]{2}{*}{ Definition } & 5 & 78. & 15 & 21. & 7 & 78. & 2 & 21. \\
\hline & 4 & 3 & & 7 & 5 & 9 & 0 & 1 \\
\hline Signs and & 5 & 78. & 1 & 21. & 6 & 63. & 3 & 36. \\
\hline $\begin{array}{l}\text { Symptom } \\
\text { ps }\end{array}$ & 4 & 3 & 5 & 7 & 0 & 2 & 5 & 8 \\
\hline \multirow[t]{2}{*}{ Causes } & 2 & 39. & 4 & 60. & 6 & 65. & 3 & 34. \\
\hline & 7 & 1 & 2 & 9 & 2 & 3 & 3 & 7 \\
\hline \multirow[t]{2}{*}{ Impact } & 4 & 65. & 2 & 34. & 6 & 70. & 2 & 29. \\
\hline & 5 & 2 & 4 & 8 & 7 & 5 & 8 & 5 \\
\hline Preventio & 5 & 76. & 1 & 23. & 8 & 89. & 1 & 10. \\
\hline $\mathrm{n}$ & 3 & 8 & 6 & 2 & 5 & 5 & 0 & 5 \\
\hline
\end{tabular}

Based on table 3, indicators of questions about the definition of anemia, it was found that the majority of respondents in the Tarongong Public Health Center had higher knowledge $(78.9 \%)$ compared to the Sukamulya Public Health Center $(78.3 \%)$. In the question and symptom question domain, it was found that the majority of respondents who knew about signs and symptoms were higher in the Sukamulya Public Health Center $(78.3 \%)$ than in the Tarogong Public Health Center (63.2\%). The domain of the question of the cause of anemia showed that the majority of respondents at the Sukamulya Public Health Center did not know the cause of anemia, which was $60.9 \%$ compared to the Tarogong Public Health Center which was only $34.7 \%$ respondents. The domain of questions regarding the impact of anemia on mothers and fetuses showed that most respondents who knew were higher in the Tarogong Public Health Center (70.5\%) compared to Sukamulya Public Health Center $(65.2 \%)$. The domain questions of anemia prevention in pregnant women showed that the majority of respondents who knew were higher in the Tarogong Public Health Center (89.5\%) compared to Sukamulya Public Health Center (76.8\%).

This finding is not in line with Nursolehah's study ${ }^{[23])}$, which stated that most mothers with sufficient category, know about anemia knowledge. Whereas in Sukamulya Public Health Center, most mothers lack knowledge about the causes of anemia, possibly influenced by the mother's experience during her pregnancy. According to Purwaningrum ${ }^{[20]}$, the experience was something that has been done or experienced by someone so that it would add insight or knowledge.

\section{Conclusion}

Based on the study that has been done, it can be concluded that the level of knowledge of pregnant women about anemia most respondents categorized had poor knowledge (46.4\%) in Sukamulya Public Health Center. Whereas in Tarogong Public Health Center most respondents were in the sufficient category $(49.5 \%)$. This study shows that there is a difference in the level of knowledge of pregnant women about anemia in Sukamulya and Tarogong Public Health Center. Respondents from the Sukamulya Public Health Center mostly knew about the definition, signs and symptoms, the impact of anemia on the mother and fetus but lack of knowledge of the causes of anemia in pregnancy. Whereas in Tarogong Public Health Center most of the respondents knew about the definition, signs and symptoms, causes of anemia in pregnant women, the impact of anemia on mothers and fetuses, and prevention of anemia in pregnant women.

\section{References}

[1] WHO. Trends in Maternal Mortality : 1990 to 2015. 2015

[2] Depkes. Profil Data Kesehatan 
Indonesia tahun 2011. 2011. http://www.depkes.go.id/downloa ds/ProfilDataKesehatanIndonesiaT ahun2011.pdf..

[3] Dinkes Jawa Barat. Profil Kesehatan Jawa Barat. J Mol Biol. 2016;301(5):1163-78. 2016.

[4] Riskesdas. HASIL UTAMA RISKESDAS 2018. 2018

[5] Kemenkes RI. Profil Kesehatan Indonesia 2015, Jakarta : Kemenkes RI. 2016.

[6] Aisyah, R. D., \& Fitriyani. Faktor Internal Dan Eksternal Yang Berhubungan Dengan Kejadian Anemia Di Wilayah Kabupaten Pekalongan. Motorik. 2016. VOL 11(No. 23), 38-52.

[7] Susiloningtyas, I. Pemberian zat besi (Fe) dalam Kehamilan. Majalah Ilmiah Sultan Agung. 2019. 50 (128), 73-99

[8] Sukmawati. Pengaruh Edukasi Pencegahan dan Penanganan Anemia. 2019; VII(1):42-7.

[9] Purbadewi, L., \& Ulvie, Y. N. S.Hubungan Tingkat Pengetahuan Tentang Anemia Dengan Kejadian Anemia Pada Ibu Hamil. Jurnal Gizi. 2013. 2(1).

[10] Dinas Kesehatan Kabupaten Garut. Profil Kesehatan Kabupaten Garut Tahun 2017. Garut . Garut : Dinas Kesehatan Kabupaten Garut. 2018.

[11] Dinas Kesehatan Kabupaten Garut. Profil Kesehatan Kabupaten Garut Tahun 2018. Garut . Garut : Dinas Kesehatan Kabupaten Garut. 2019.

[12] Notoadmodjo, S. Metode Penelitian Kesehatan. Jakarta: Rineka Cipta. 2014.

[13] Bernaix, I. W., Beaman, M. L., Schmidt, C. A., Harris, J. K., \& Miller, L. M. Success of an educational intervention on maternal/newborn nurses'breastfeeding knowledge and attitudes. Journal of Obstetric, Gynecologic \& Neonatal Nursing. 2010.39(6), 658-666. https://10.1111/j.15526909.2010. 01184.x.

[14] Wijayanti, A. Perbedaan Tingkat Pengetahuan Ibu Hamil Sebelum dan Setelah diberikan Penyuluhan tentang Anemia Gizi Besi dengan menggunakan Media Booklet di Puskesmas Getak (Doctoral dissertation, Universitas Muhammadiyah Surakarta). 2015.

[15] Martini, S., \& Saroh, E. N. "Gambaran tingkat pengetahuan ibu hamil tentang tabu makanan pada ibu hamil anemia." Jurnal Kesehatan Ibu dan Anak Akademi Kebidanan An-Nur. 2018. 3(1).

[16] Wulandini,S,P., Triska, T. Hubungan pengetahuan ibu hamil tentang anemia dengan kepatuhan mengkonsumsi tablet fe di wilayah puskesmas ri karya wanita pekanbaru tahun 2017. Jurnal Maternity and Neonatal2018. Vol, 2(5), 300 .

[17] Amini, A., Pamungkas, C. E., \& Harahap, A. P. H. P. Usia Ibu dan Paritas sebagai Faktor Risiko yang Mempengaruhi Kejadian Anemia pada Ibu Hamil di Wilayah Kerja Puskesmas Ampenan. Midwifery Journal, 3(2). 2018. 108-113.

[18] Nugroho, H.A. \& Nurdiana, D. Hubungan Antara Pengetahuan dan Motivasi Kader Posyandu dengan Keaktifan Kader Posyandu di Desa Dukuh Tengah Kecamatan Ketanggungan Kabupaten Brebes. Jurnal Keperawatan. 2008. 2(1): 1-8.

[19] Solehati, T., Sari, C. W. M., Lukman, M., \& Kosasih, C. E.Pengaruh Pendidikan Kesehatan Terhadap Pengetahuan Deteksi Dini Dan Pencegahan Anemia Dalam Upaya Menurunkan AKI Pada Kader Posyandu. Jurnal Keperawatan Komprehensif,. 2018. 4(1), 7-12.

[20] Purwaningrum Y. ISSN : 23545852 Pengetahuan Ibu Hamil tentang Gizi dengan Kejadian Anemia Selama Kehamilan ISSN : 
2354-5852. 2017;5(2):88-93.

[21] Handayani. Peran petugas kesehatan dan kepatuhan ibu hamil mengkonsumsi tablet besi. 2013;7(2):83-8. 2013.

[22] Solehah, N. Gambaran tingkat pengetahuan ibu hamil tentang anemia di puskesmas godean ii kabupaten sleman. 2017.

[23] Kusumawati, Bangun Tri, 'Gambaran Tingkat Pengetahuan Ibu Hamil Tentang Anemia Pada Kehamilan Di Desa Gundik Wilayah Kerja Puskesmas Nailan Slahung Ponorogo'. 2012. 